\author{
PIOTR MARCIN WIÓREK \\ ORCID: 0000-0003-2478-8341 \\ Uniwersytet Wrocławski \\ Instytut Prawa Cywilnego \\ Zakład Prawa Gospodarczego i Handlowego
}

\title{
WPROWADZENIE NOWEGO TYPU SPÓŁKI KAPITAŁOWEJ (PROSTEJ SPÓŁKI AKCYJNEJ) DO KODEKSU SPÓŁEK HANDLOWYCH A ZAŁOŻENIE RACJONALNEGO PRAWODAWCY
}

\begin{abstract}
Abstrakt: Celem niniejszego artykułu jest odpowiedź na pytanie, czy wprowadzając nowy typ spółki kapitałowej w postaci prostej spółki akcyjnej, ustawodawca polski postąpił zgodnie z założeniami racjonalnego prawodawcy. Przeprowadzona analiza prowadzi — niestety — do wniosku, że tak się nie stało. Zamiast dokonać punktowej regulacji rozwiązującej rzeczywiste potrzeby środowiska startupowego w postaci chociażby specustawy, została powołana do życia nowa forma spółki kapitałowej, która z uwagi nie tylko na obszerność jej regulacji, lecz przede wszystkim na jej treść, rozsadza w istocie system polskiego prawa spółek, niosąc z sobą wiele ryzyk dla stabilności tego systemu. Dlatego należy postulować, aby de lege ferenda ustawodawca uchylił przepisy ją regulujące.
\end{abstract}

Słowa kluczowe: prosta spółka akcyjna, Zasady techniki prawodawczej, startup, inwentor, spółka kapitałowa, racjonalny prawodawca

\section{WPROWADZENIE}

Dnia 19 lipca 2019 roku została uchwalona ustawa o zmianie ustawy - Kodeks spółek handlowych oraz niektórych innych ustaw ${ }^{1}$, która wprowadza do Kodeksu spółek handlowych ${ }^{2}$, a tym samym do polskiego prawa spółek z dniem 1 marca 2020 roku, nowy typ spółki kapitałowej w postaci prostej spółki akcyjnej określanej w skrócie jako PSA ${ }^{3}$. Proponowane wspomnianą nowelą zmiany KSH

${ }^{1}$ Ustawa z dnia 19 lipca 2019 roku o zmianie ustawy - Kodeks spółek handlowych oraz niektórych innych ustaw, Dz.U. z 2019 r. poz. 1655.

2 Ustawa z dnia 15 września 2000 roku — Kodeks spółek handlowych, tekst jedn. Dz.U. z 2019 r. poz. 505 z późn. zm.; dalej: KSH.

3 Oficjalny skrót tej spółki, zgodnie z art. $300^{8} \S 2 \mathrm{KSH}$, to P.S.A. 
wywołały (już na wstępnym etapie procesu legislacyjnego) wiele kontrowersji i najbardziej chyba burzliwą od wielu lat dyskusję w doktrynie prawa spółek porównywalną jedynie do tej, jaka towarzyszyła niedoszłej do skutku reformie struktury majątkowej spółki z o.o. ${ }^{4}$ Wprowadzenie do polskiego prawa spółek nowego typu spółki kapitałowej spotkało się ze stanowczym oporem większości komercjalistów ${ }^{5}$, czego przejawem było między innymi ukonstytuowanie się Forum Katedr Prawa Handlowego, w ramach którego sformułowano obszerne uwagi krytyczne do projektu noweli wprowadzającej PSA, zgłoszone ówczesnemu Ministerstwu Przedsiębiorczości i Technologii jako projektodawcy, a także bezprecedensowe wystosowanie przez przedstawicieli tego środowiska w dniu 5 kwietnia 2019 roku listu otwartego adresowanego do posłów i senatorów RP, w którym zaapelowano o nieuchwalanie zmiany KSH wprowadzającej PSA do polskiego porządku prawnego ${ }^{6}$. W ramach krytyki nowej regulacji kwestionowano między innymi jej zgodność z zasadami techniki prawodawczej, co z kolei — w szerszym ujęciu — rodzi pytanie o to, czy została ona zaprojektowana i uchwalona w zgodzie z wymogami, których spełnienia oczekuje się od prawodawcy faktycznego, a zatem, czy prawodawca, wprowadzając do polskiego prawa spółek nowy typ spółki kapitałowej w postaci PSA, zachował się jak prawodawca racjonalny, czy też oddalił się od tego wzorca. Celem niniejszego artykułu jest odpowiedź na to pytanie.

\section{ZAŁOŻENIE RACJONALNEGO PRAWODAWCY W PRAWOZNAWSTWIE}

W opracowaniach z zakresu teorii prawa szczególną uwagę poświęca się problemowi racjonalnego stanowienia prawa, rozwijając koncepcję racjonalnego prawodawcy. W opracowaniach dogmatyczno-prawnych poświęconych analizie obowiązujących przepisów również odwołuje się do tego pojęcia, najczęściej poddając krytyce poszczególne rozwiązania prawne i postulując zmianę danej regu-

${ }^{4}$ O burzliwości tej dyskusji świadczą dobitnie niektóre tytuły artykułów krytykujących tę nową formą organizacyjno-prawną. Zob. chociażby A. Kidyba, Pierwsze uderzenie w PSA, „Dziennik Gazeta Prawna" 27.12.2016; idem, Drugie zabicie PSA. Trzy bariery dla start-upów staty się uzasadnieniem dla wyprodukowania około 200 przepisów, „Dziennik Gazeta Prawna” 20.03.2018; M. Romanowski, TSA, czyli Trudna Spółka Akcyjna, https://www.prawo.pl/prawnicy-sady/tsa-czyli-trudna-spolka-akcyjna,73145.html (dostęp: 13.05.2020). W dyskusji tej zabrał głos również autor niniejszego artykułu. Zob. P.M. Wiórek, O braku potrzeby wprowadzenia prostej spółki akcyjnej (PSA) z perspektywy prawnoporównawczej, „Przegląd Prawa Handlowego” 2018, nr 5, s. 4 n.; idem, Czy potrzeba nam szczególnej formy organizacyjno-prawnej dla innowacyjnego biznesu? Uwagi ogólne na podstawie uzasadnienia projektu prostej spótki akcyjnej — PSA, „Przegląd Prawa i Administracji” 112, 2018, s. 233 n.

5 Jak określa się przedstawicieli doktryny prawa handlowego i prawa spółek.

${ }^{6}$ Zob. List otwarty do postów i senatorów RP w sprawie zmian w Kodeksie spótek handlowych, „Rzeczpospolita” 5.04.2019. 
lacji. Ramy niniejszego artykułu nie pozwalają na szersze omówienie niezmiernie ciekawej - z punktu widzenia dogmatyki prawa handlowego — problematyki prawodawcy racjonalnego. $Z$ uwagi na temat przewodni niniejszego jubileuszowego tomu i treść innych artykułów w nim zawartych wydaje się to zresztą zbyteczne. Wystarczy w tym miejscu zwrócić uwagę na podstawowe kwestie dotyczące pojęcia prawodawcy racjonalnego, relewantne dla omawianej problematyki.

I tak - należy przede wszystkim podkreślić, że „prawodawca racjonalny” stanowi wzór dla prawodawcy faktycznego, ujmowanego najczęściej w kategoriach instytucjonalnych i normatywnych ${ }^{7}$, do którego ów ,prawodawca faktycznie tworzący normy prawne powinien się zbliżać"8. Można go więc uznać za ideał, do którego prawodawca faktyczny powinien dążyć ${ }^{9}$. Prawodawca racjonalny to podmiot, „który w swoim działaniu kieruje się, w szczególny sposób, swą wiedzą i ocenami: spośród dostępnych mu w danej sytuacji czynności wykonuje tę, która na gruncie jego wiedzy prowadzi do rezultatu najwyżej przezeń cenionego" ${ }^{10}$. Racjonalizm prawodawcy przejawia się w tym, że opracowuje on i realizuje „prakseologiczny plan działania”, w ramach którego wyraźnie wyznacza cel swojego działania „w stopniu dostatecznie sprecyzowanym dla wyboru środków służących jego realizacji" oraz formułuje katalog potencjalnych prawnych lub pozaprawnych środków służących realizacji tego celu, co pozwala mu podjąć decyzję o zastosowaniu bądź nie środków prawnych. Jeśli zaś zdecyduje się na „zastosowanie prawnych środków oddziaływania", wybiera nie tylko formę projektowanego aktu prawnego, lecz również precyzuje jego cel, biorąc pod uwagę alternatywne sposoby unormowania danej dziedziny ${ }^{11}$.

Innymi słowy — prawodawca racjonalny dokładnie określa cel swego działania i w sposób optymalny dobiera środki służące jego osiągnięciu. A zatem postępuje zgodnie z zasadą brzytwy Ockhama i nie mnoży bytów ponad potrzebę ${ }^{12}$.

${ }^{7}$ Za instytucjonalnym ujęciem prawodawcy faktycznego określanego w związku z tym jako „prawodawca instytucjonalny” opowiada się S. Wronkowska. Zob. eadem, Prawodawca racjonalny jako wzór dla prawodawcy faktycznego, [w:] Szkice z teorii prawa i szczegółowych nauk prawnych ofiarowane Profesorowi Zygmuntowi Ziembińskiemu, red. S. Wronkowska, M. Zieliński, Poznań 1990, s. 119.

8 Zob. ibidem, s. 121.

9 Jak podkreśla się w teorii prawa, ,założenia konstytuujące prawodawcę racjonalnego (i odpowiednio doskonałego) merytorycznie idealizują wiedzę i oceny prawodawcy faktycznie tworzącego prawo". Zob. ibidem, s. 130.

10 Ibidem, s. 120 i przywołana tam literatura. Cytowana autorka posługuje się dodatkowo pojęciem ,prawodawcy doskonałego”, który spełnia ponadto dodatkowe wymogi sformułowane przez prawników, w szczególności dysponuje najlepszą — a nie ,jedynie” odpowiednią, jak w przypadku prawodawcy racjonalnego - wiedzą faktyczną, językową i wiedzą o systemie prawnym i postępuje według kryteriów wypracowanych przez „współczesną mu metodologię nauk” (zob. ibidem, s. 120, $126,128)$.

11 Obszernie na ten temat zob. ibidem, s. 125-126.

12 Łacińska paremia wyrażająca tę zasadę ekonomii myślenia to Entia non sunt multiplicanda praeter necessitatem (Nie należy mnożyć bytów ponad potrzebę"). Zob. https://pl.wikipedia. 
Prawodawca racjonalny jest ponadto prawodawcą racjonalnym merytorycznie urzeczywistniającym trzy podstawowe założenia: o racjonalności aksjologicznej, o wiedzy faktycznej oraz o wiedzy językowej prawodawcy ${ }^{13}$.

\section{ZAŁOŻENIE RACJONALNEGO PRAWODAWCY W ZASADACH TECHNIKI PRAWODAWCZEJ}

Założenie racjonalnego prawodawcy znajduje swój wyraz w Zasadach techniki prawodawczej ${ }^{14}$, które nakazują prawodawcy faktycznemu przestrzeganie określonych reguł w procesie tworzenia prawa. Dla dalszych rozważań szczególnie istotne są wymogi określone w $\S 1$ ust. 1 pkt 1-3, a także w $\S 1$ ust. 2 pkt 1-4 ZTPR. Z przepisów tych wynika obowiązek ustalenia przez prawodawcę faktycznego, czy rzeczywiście wymagana jest interwencja prawodawcza w danej dziedzinie, a jeśli tak — obowiązek klarownego przedstawienia celów, które ustawodawca zamierza osiągnąć oraz ustalenia ${ }^{15}$, czy istnieją rozwiązania prawne alternatywne, „które mogą skutecznie służyć osiągnięciu założonych celów”"16, a także sformułowania „prognozy podstawowych i ubocznych skutków zamierzonych rozwiązań prawnych alternatywnych, w tym wpływu tych rozwiązań na system prawa" ${ }^{17}$; wreszcie projektodawca powinien „dokonać wyboru optymalnego w danych warunkach rozwiązania prawnego"18.

\section{PROSTA SPÓŁKA AKCYJNA JAKO NOWY TYP SPÓŁKI KAPITAŁOWEJ A ZAŁOŻENIE RACJONALNEGO PRAWODAWCY}

Nowo wprowadzana do KSH prosta spółka akcyjna jest, jak podkreśla się w uzasadnieniu do projektu ustawy o zmianie ustawy — Kodeks spółek handlo-

\footnotetext{
org/wiki/Brzytwa_Ockhama (dostęp: 13.05.2020). Na temat kierowania się przez Zasady techniki prawodawczej zasadą brzytwy Ockhama por. M. Romanowski, Opinia. Ocena projektu ustawy o zmianie ustawy - Kodeks spótek handlowych oraz niektórych innych ustaw (Druk nr 3236), zwany dalej projekt, Warszawa 12.03.2019, sporządzona na zlecenie Biura Analiz Sejmowych, s. 8.

13 Zob. szerzej ibidem, s. 132.

14 Rozporządzenie Prezesa Rady Ministrów z dnia 20 czerwca 2002 roku w sprawie „Zasad techniki prawodawczej”, tekst jedn. Dz.U. z 2016 r. poz. 283; dalej: ZTPR. Wspomniane zasady zawarte są w załączniku do tego rozporządzenia.

15 Por. $\S 1$ ust. 2 pkt 2 ZTPR.

$16 \S 1$ ust. 2 pkt 3 ZTPR.

$17 \S 1$ ust. 2 pkt 4 ZTPR.

$18 \S 1$ ust. 2 pkt 6 ZTPR.
} 
wych oraz niektórych innych ustaw ${ }^{19}$, „,nowoczesną formą niepublicznej spółki kapitałowej przeznaczoną dla innowacyjnych przedsięwzięć" ${ }^{20}$. Ma ona

łączyć korporacyjny charakter spółki jako osoby prawnej i jego podstawowy przejaw, jakim jest wyłączenie osobistej odpowiedzialności wspólników za jej zobowiązania ze znaczną swobodą kształtowania stosunku spółki, zarówno jeśli chodzi o wzajemne relacje pomiędzy wspólnikami, jak i system zarządzania spółką oraz nadzoru nad tym procesem²1.

Od pozostałych spółek kapitałowych odróżnia się przede wszystkim charakterystyczną dla spółek osobowych dopuszczalnością wnoszenia do niej jako wkładów pracy lub usług na pokrycie akcji, odstąpieniem od instytucji kapitału zakładowego i towarzyszącym temu uelastycznieniem wypłat dla akcjonariuszy z majątku spółki, wprowadzeniem akcji beznominałowych, nieograniczoną swobodą kształtowania akcji uprzywilejowanych, dopuszczeniem procedury „uproszczonej” likwidacji spółki oraz nowoczesnym mechanizmem ochrony wierzycieli spółki ${ }^{22}$.

Powodem wprowadzenia tego nowego typu spółki jest, zdaniem projektodawcy, w uproszczeniu - niedostosowanie dotychczasowych typów spółek kapitałowych — spółki z o.o. i spółki akcyjnej — do potrzeb przedsięwzięć typu startup. Głównymi mankamentami spółki z o.o. są: 1) trudności w takim ukształtowaniu relacji w spółce, „by silna pozycja wspólnika była powiązana nie tyle z wkładem majątkowym, co z jego osobistymi zdolnościami i pracą, czyli z kapitałem ludzkim wykorzystywanym przez spółkę", a także 2) skomplikowany charakter inwestycji w spółkę z o.o., czego z kolei przejawem, zdaniem projektodawcy, są: a) wymóg zachowania formy pisemnej z podpisami notarialnie poświadczonymi dla umowy przenoszącej udziały w spółce, b) brak posiadania przez udziały cechy papierów wartościowych, c) ograniczone możliwości uprzywilejowania udziałów, d) brak możliwości utworzenia udziałów niemych, e) zbyt wysoka, bo wynosząca aż 50 złotych, minimalna wartość nominalna udziału, co ogranicza korzystanie przez spółki z crowdfundingu, i wreszcie f) niedopuszczalność wnoszenia do spółki z o.o. wkładów w postaci pracy lub usług, co należy powiązać z trudnością przedstawioną powyżej (w pkt 1$)^{23}$. Z kolei spółka akcyjna nie jest ze swej istoty, z uwagi na jej cechy, w tym zwłaszcza wysokość minimalnego kapitału zakładowego w kwocie 100 tysięcy złotych oraz obowiązującą w niej zasadę surowości statutu, przystosowana do innowacyjnych przedsięwzięć (zwłaszcza na ich początkowym etapie) ${ }^{24}$.

Z tych względów ustawodawca zdecydował się na wprowadzenie PSA jako nowego typu spółki kapitałowej stanowiącej „,połączenie w jednej formie prawnej

19 Projekt ustawy o zmianie ustawy — Kodeks spółek handlowych i innych ustaw (druk sejmowy nr 3236, VIII kadencja); dalej: Projekt.

${ }^{20}$ Uzasadnienie Projektu, s. 1.

21 Uzasadnienie Projektu, s. 1.

22 Zob. szerzej poszczególne części uzasadnienia Projektu.

23 Zob. uzasadnienie Projektu, s. 3-4.

${ }^{24}$ Zob. szerzej uzasadnienie Projektu, s. 4-5. 
elementów właściwych" dla spółki z o.o. i spółki akcyjnej25 i cechującej się większym od nich stopniem elastyczności w kształtowaniu jej struktury i relacji między jej udziałowcami. Jednakże w uzasadnieniu Projektu wyraźnie podkreśla się, że PSA będzie mogła być wykorzystywana „nie tylko do prowadzenia działalności opartej na innowacjach", zwłaszcza w środowisku startupowym, co stanowiło impuls do rozpoczęcia prac nad koncepcją tej nowej formy spółki kapitałowej, lecz stanowić będzie formę odpowiadającą ,,potrzebom innych nowoczesnych przedsięwzięććc".

Ograniczone ramy objętościowe niniejszego artykułu nie pozwalają na obszerną krytykę nowej regulacji i „wypunktowanie” wszystkich jej mankamentów. W tym miejscu należy zwrócić uwagę jedynie na „grzechy główne” nowego rozwiązania, które uzasadniają postawienie tezy, że ustawodawca, wprowadzając nowy typ spółki kapitałowej, jako prawodawca faktyczny nie spełnił wymogów stawianych racjonalnemu prawodawcy.

Po pierwsze, nazwa nowej spółki kapitałowej — „prosta spółka akcyjna” — wprowadza w błąd. PSA nie jest mianowicie ani spółką akcyjną, czy chociażby jej odmianą (lub podtypem), ani tym bardziej spółką ,prostą". Sam ustawodawca przyznał, że stanowi ona rozwiązanie podwójnie hybrydalne, łącząc w sobie cechy zarówno spółki kapitałowej i osobowej (co w samo w sobie nie zasługuje na krytykę, bo tego rodzaju hybrydą jest w istocie, również na gruncie obecnie obowiązujących przepisów, spółka z o.o.), jak i obydwu spółek kapitałowych (akcyjnej i z o.o.), przy czym można się spierać, które elementy (spółki z o.o. czy akcyjnej) przeważają. Już samo to może wprowadzać w błąd uczestników obrotu i z jednej strony pozwala korzystać PSA z renomy, jaką cieszy się spółka akcyjna (bo nazwa taka kojarzy się dobrze), z drugiej zaś w praktyce może prowadzić, w istocie, do nadwyrężenia reputacji samej spółki akcyjnej jako spółki kapitałowej (jeżeli obrót zacznie przenosić negatywne skojarzenia narastające wokół PSA, co prawdopodobnie nastąpi, na „właściwy” typ spółki, jaką jest S.A.). PSA w żadnym wypadku nie jest spółką prostą. Jej regulacja zajmuje bowiem w KSH aż 134 artykuły, pomijając odesłania do stosowania przepisów o spółce z o.o. i spółce akcyjnej, w przeciwieństwie chociażby do „wzorcowej” regulacji francuskiej société par actions simplifiée (SAS), która składa się z 27 artykułów. Poza tym stosowanie nowych przepisów będzie naprawdę skomplikowane. Pomijając ich liczbę, trzeba będzie rozwiązywać wiele wątpliwości interpretacyjnych, które one z sobą niosą ${ }^{27}$.

25 Zob. uzasadnienie Projektu, s. 5.

26 Zob. ibidem.

27 Co podkreśla się we wszystkich opiniach zewnętrznych na temat Projektu sporządzonych na zlecenie Biura Analiz Sejmowych. Zob. A. Kappes, Opinia prawna w przedmiocie oceny rzadowego projektu ustawy o zmianie ustawy kodeks spółek handlowych i niektórych innych ustaw - nr RM10-11-19 - nr druku sejmowego (3236), zwanego dalej „Projektem”, Warszawa 12.02.2019; P. Pinior, Ekspertyza prawna dotyczaca rzadowego projektu ustawy o zmianie ustawy - Kodeks spótek handlowych oraz niektórych innych ustaw (druk nr 3236), Warszawa 12.03.2019; M. Romanowski, Opinia. Ocena projektu ustawy...; podkreśla to zwłaszcza P. Pinior, podnosząc ponadto, że nowa regulacja „cechuje się nadmierną kazuistyką” (zob. idem, Opinia. Ocena projektu ustawy..., s. 4). 
Po drugie, ustawodawca w niewystarczającym stopniu zbadał, czy istnieje rzeczywista potrzeba wprowadzenia nowej, tak kompleksowej i skomplikowanej, regulacji, jaką są przepisy o PSA, i w niedostateczny sposób pochylił się nad rozwiązaniami prawnymi alternatywnymi pozwalającymi spełnić oczekiwania tak zwanych inwentorów ze środowiska startupowego. W szczególności za niewystarczający jako impuls do powołania do życia nowej formy prawnej należy uznać wynik ankiety przeprowadzonej w środowisku inwentorów, zgodnie z którym $73 \%$ badanych przedsiębiorców ,widzi potrzebę wprowadzenia nowego typu spółki, która mogłaby być wykorzystywana w działalności innowacyjnej”28.

Po trzecie, w nawiązaniu do poprzedniego zastrzeżenia, ustawodawca na uzasadnienie potrzeby stworzenia nowego typu spółki przytoczył w istocie zbyt błahe powody, przedstawione powyżej w pkt 2) a), b), d), e), które to „niedoskonałości” sp. z o.o. można łatwo usunąć (wręcz „od ręki”) prostą nowelą KSH, natomiast w odniesieniu do pkt 2 c) i f) w doktrynie dopuszcza się możliwość wprowadzenia stosownych zmian $w$ ramach sp. z o.o., co musiałoby być jednak poprzedzone większą dyskusją ${ }^{29}$. Z całą pewnością wymagałoby to wprowadzenia (w przypadku pkt 2 c) i f)) dodatkowych rozwiązań chroniących wspólników i wierzycieli. Ustawodawca mógł śmiało skorzystać z przywołanych przez niego w uzasadnieniu wzorców reformatorskich — chociażby przejąć rozwiązania przyjęte w tak zwanej holenderskiej „flex-BV"30, jednak, niestety, nie zdecydował się na to rozwiązanie.

Po czwarte, biorąc pod uwagę rzeczywiste potrzeby inwentorów i główne mankamenty polskiej regulacji, wyraźnie zdiagnozowane w przywołanym w uzasadnieniu Projektu raporcie Deloitte z czerwca 2016 roku pod tytułem „Diagnoza ekosystemów startupów w Polsce ${ }^{31}$ ", jakimi są — przede wszystkim — skomplikowany i nieprzejrzysty system podatkowy ${ }^{32}$, właściwszym legislacyjnym rozwiązaniem byłoby stworzenie dla środowiska startupowego specustawy ${ }^{33}$ przyznającej innowacyjnym przedsiębiorcom określone ulgi „na starcie” (a nie tworzenie dla nich mon-

${ }^{28}$ Zob. uzasadnienie Projektu, s. 3. Jak podkreśla się w doktrynie, można się spodziewać, że gdyby skierowano odpowiednią ankietę do przedsiębiorców z różnych branż, ci uznaliby, że potrzebują dopasowanej do ich działalności nowej formy spółki prawnej. Por. A. Kidyba, Pierwsze uderzenie..., P.M. Wiórek, Czy potrzeba nam szczególnej formy..., s. 239.

29 Szerzej na ten temat M. Romanowski, Opinia. Ocena projektu ustawy ..., s. 13 n.

${ }^{30}$ Zob. uzasadnienie Projektu, s. 6. Na temat holenderskiej reformy spółki z o.o. zob. również P.M. Wiórek, O braku potrzeby..., s. 6 i przywołana tam literatura.

31 Deloitte, Diagnoza ekosystemu startupów w Polsce, czerwiec 2016, https://www2.deloitte.com/content/dam/Deloitte/pl/Documents/Reports/pl_Deloitte_raport_startupy.pdf; dalej: raport Deloitte (dostęp: 13.05.2020). Raport ten przedstawia tak zwany model dojrzałości ekosystemów startupów na podstawie analizy obszarów ich funkcjonowania, takich jak: finansowanie, regulacje prawne, kapitał ludzki, kapitał społeczny oraz otoczenie instytucjonalne, dokonanej w czterdziestu państwach. Szerzej na ten temat zob. P.M. Wiórek, Czy potrzeba nam szczególnej formy..., s. 235 n.

32 Zob. P.M. Wiórek, Czy potrzeba nam szczególnej formy..., s. 236-237.

33 W doktrynie polskiej za stworzeniem specustawy dla startupów opowiedział się również M. Romanowski, Opinia. Ocena projektu ustawy..., s. 16. 
strualnego i skomplikowanego wehikułu w celu prowadzenia przez nich działalności gospodarczej), wzorowanej chociażby na rozwiązaniach przyjętych we Włoszech ${ }^{34}$.

Po piąte, i w nawiązaniu do poprzedniego zastrzeżenia, ustawodawca, chcąc zaradzić rzekomym problemom i zaspokoić potrzeby wąskiej grupy przedsiębiorców, zamiast stworzyć dla nich specustawę, stworzył rozwiązanie dla wszystkich podmiotów, co jeszcze bardzie wskazuje na to, że „przestrzelił się” on regulacyjnie.

Po szóste, ustawodawca, wprowadzając tak skomplikowaną i rozbudowaną konstrukcję, jaką jest PSA, w celu realizacji założonych celów wykroczył znacznie poza naznaczoną tymi celami potrzebę regulacyjną, naruszając zasadę brzytwy Ockhama. Stworzył on mianowicie byt ponad potrzebę, nadmierną i kazuistyczną regulację, na którą, jak już wspomniano, składają się ponad 134 artykuły (do czego należy doliczyć przepisy o spółce z o.o. i akcyjnej, do których odsyłają przepisy o PSA).

Po siódme, regulacja PSA jest wręcz szkodliwa pod względem systemowym, ponieważ rozbija system prawa spółek ujęty w ramach kodeksu spółek handlowych ${ }^{35}$. Ujmując problem obrazowo, można stwierdzić, że wżyna się ona klinem w regulację prawa spółek, przecinając niejako na pół KSH i tworząc enklawę regulacyjną w ramach tego Kodeksu, która może „skontaminować”, chociażby przez wywoływane przez nią wątpliwości interpretacyjne, całą jego regulację. Stanowi ona swego rodzaju koncert życzeń i koktajl różnych rozwiązań prawnych połączony w jedną instytucjonalną hybrydę - swoisty poligon doświadczalny dla prawodawcy. Ustawodawca wydaje się przy tym nie zdawać sprawy z zagrożeń, jakie niesie z sobą ta nowa forma prawna, na które to zagrożenia zwracano uwagę w dyskusji naukowej i fachowej poprzedzającej uchwalenie ustawy. Spośród wielu zagrożeń, oprócz podnoszonych w owej dyskusji deficytów nowej regulacji w zakresie ochrony wierzycieli oraz zagrożenia, że może ona stanowić nie tyle wehikuł dla działalności innowacyjnej, co wehikuł do nadużyć, warto zwrócić uwagę na jedno istotne zagrożenie. Otóż PSA w przyszłości może potencjalnie wyprzeć spółkę z o.o. jako dominującą w polskim systemie prawa spółek formę organizacyjno-prawną, choć akurat dużo tutaj będzie zależeć od stopnia rozpropagowania PSA jako nowej formy spółki kapitałowej przez adwokatów, radców prawnych i innych doradców prawnych.

\section{ZAKOŃCZENIE}

Kończąc niniejsze rozważania, należy z przykrością stwierdzić, że ustawodawca, jako prawodawca faktyczny, wprowadzając do polskiego prawa spółek i do Kodeksu spółek handlowych nowy typ spółki kapitałowej, dokonał tego w sposób sprzeczny z założeniami racjonalnego prawodawcy. W celu rozwiązania $\mathrm{w}$ istocie kilku problemów nielicznej (póki co) grupy przedsiębiorców, stworzył on kom-

34 Szerzej na ten temat zob. P.M. Wiórek, O braku potrzeby..., s. 5-6.

35 Słusznie zwraca na to uwagę m.in. M. Romanowski, Opinia. Ocena projektu ustawy..., s. 16. 
pleksowe i skomplikowane rozwiązanie prawne adresowane do wszystkich przedsiębiorców, które już w samej nazwie — prosta spółka akcyjna — jest sprzeczne samo w sobie. PSA nie jest bowiem ani spółką akcyjną, ani tym bardziej ,prostą" spółką. Forma ta niesie z sobą więcej ryzyk dla systemu polskiego prawa spółek, niż przynosi przewidywanych korzyści. Dlatego należy postulować de lege feren$d a$, aby ustawodawca uchylił przepisy ją regulujące ${ }^{36}$.

\title{
INTRODUCTION OF A NEW TYPE OF CAPITAL COMPANY (SIMPLE JOINT STOCK COMPANY) TO THE POLISH COMMERCIAL COMPANIES CODE AND THE PRINCIPLE OF A RATIONAL LEGISLATOR
}

\author{
Summary
}

The purpose of the article is to answer the question whether, when introducing a new type of capital company in the form of a simple joint stock company, the Polish legislator has acted in accordance with the assumptions of a rational legislator. Unfortunately, the analysis carried out in the study leads to the conclusion that this did not happen. Instead of introducing punctual regulations solving the real needs of the startup environment in the form of, for example, a special law, a new form of capital company was created, which, not only because of the extensiveness of its regulation, but above all because of its content, actually breaks the Polish company law system, bringing many risks to the stability of this system. Therefore, it should be postulated that, de lege ferenda, the legislator repeal the provisions governing it.

Keywords: simple joint stock company, rules of legislative technique, startup, inventor, corporation, rational legislator

\section{BIBLIOGRAFIA}

Deloitte, Diagnoza ekosystemu startupów w Polsce, czerwiec 2016, https://www2.deloitte.com/content/dam/Deloitte/p1/Documents/Reports/pl_Deloitte_raport_startupy.pdf.

Kappes A., Opinia prawna w przedmiocie oceny rzadowego projektu ustawy o zmianie ustawy kodeks spótek handlowych i niektórych innych ustaw - nr RM-10-11-19 - nr druku sejmowego (3236), zwanego dalej „Projektem”, Warszawa 12.02.2019, sporządzona na zlecenie Biura Analiz Sejmowych.

Kidyba A., Drugie zabicie PSA. Trzy bariery dla start-upów stały się uzasadnieniem dla wyprodukowania około 200 przepisów, „Dziennik Gazeta Prawna” 20.03.2018.

Kidyba A., Pierwsze uderzenie w PSA, „Dziennik Gazeta Prawna” 27.12.2016.

List otwarty do posłów i senatorów RP w sprawie zmian w Kodeksie spótek handlowych, „Rzeczpospolita" 5.04.2019.

36 O tym, że ta nowa forma prawna wywołuje problemy praktyczne już od samego początku, świadczy informacja, która ostatnio obiegła prasę. Zob. Sejmowa komisja przesunęła termin wejścia w życie Prostej Spótki Akcyjnej o rok, „Dziennik Gazeta Prawna”, 8.01.2020, https://prawo.gazetaprawna.pl/artykuly/1447496,termin-wejscia-w-zycie-prostej-spolki-akcyjnej-za-rok.html. 
Pinior P., Ekspertyza prawna dotyczaca rzadowego projektu ustawy o zmianie ustawy - Kodeks spótek handlowych oraz niektórych innych ustaw (druk nr 3236), Warszawa 12.03.2019, sporządzona na zlecenie Biura Analiz Sejmowych.

Romanowski M., Opinia. Ocena projektu ustawy - o zmianie ustawy - Kodeks spótek handlowych oraz niektórych innych ustaw (Druk $n r$ 3236), zwany dalej projekt, Warszawa 12.03.2019, sporządzona na zlecenie Biura Analiz Sejmowych.

Romanowski M., TSA czyli Trudna Spótka Akcyjna, https://www.prawo.pl/prawnicy-sady/tsa-czyli-trudna-spolka-akcyjna, 73145.html.

Sejmowa komisja przesunęła termin wejścia w życie Prostej Spółki Akcyjnej o rok, „Dziennik Gazeta Prawna”, 08.01.2020, https://prawo.gaetaprawna.pl/artykuly/1447496,termin-wejscia-w-zycie-prostej-spolki-akcyjnej-za-rok.html.

Wiórek P.M., Czy potrzeba nam szczególnej formy organizacyjno-prawnej dla innowacyjnego biznesu? Uwagi ogólne na podstawie uzasadnienia projektu prostej spótki akcyjnej — PSA, „Przegląd Prawa i Administracji” 112, 2018.

Wiórek P.M., O braku potrzeby wprowadzenia prostej spótki akcyjnej (PSA) z perspektywy prawnoporównawczej, „Przegląd Prawa Handlowego” 2018, nr 5.

Wronkowska S., Prawodawca racjonalny jako wzór dla prawodawcy faktycznego, [w:] Szkice z teorii prawa i szczególowych nauk prawnych ofiarowane Profesorowi Zygmuntowi Ziembińskie$m u$, red. S. Wronkowska, M. Zieliński, Poznań 1990. 